Наталија Д. Синановић"

\title{
ОБРАЗОВАЊЕ И МЕДИЈИ
}

Транзиција је оставила дубок траг како у земљама у региону, тако и у Србији. Образовни систем тешко је мењати, али га је исто тако тешко изнова градити. Потребна је добра стратегија и контрола квалитета. Образовне реформе не значе само промену закона, програма и садржаја, оне подразумевају и стално усавршавање и наставе и наставника. Главни актери високог образовања: студенти, професори, декани, ректори универзитета, владе, министартствав просвете, науке истовремено су у главној улози и на програмима медија о високом образовању. Теоретичари сматрају да медији немају слободу да стварају непостојеће друштвене вредности, иако могу утицати на начин на који ће се друштвене вредносту исказивати. Отуда и питање да ли су и колико су те поруке и садржаји утицали на процес реформе високог образовања, а реформа на садржај и програме медија?

Кључе речи: реформа високог образовања, универзитет, професори, студенти, медији, РТС, управљање знањем, гледаност, утицај

\section{О образовању}

Транзиција је оставила дубок траг како у земљама у региону, тако и у Србији. Образовни систем тешко је мењати, али га је исто тако тешко изнова градити. Потребна је добра стратегија и контрола квалитета. Образовне реформе не значе само промену закона, програма и садржаја, оне подразумевају и стално усавршавање и наставе и наставника. У готово свим републикама некадашње Југославије дилеме и проблеми су готово идентични. За успешност образовних реформи, веома су важни и добри програми и добри професори јер су они директно одговорни за успех ученика. Зато треба наћи начина

Радио-телевизија Србије, Таковска бр. 10, 11000 Београд, e-mail: natalija. sinanovic@rts.rs 
да се најбољи студенти определе за наставничку професију како би се створили бољи образовни системи, а самим тим и јаче економије.

Европској унији у овом тренутку незапослено 25\% младих. То не значи да постоји мањак радних места, јер их је непопуњено око милион. Већ то говори о неусклађености образовања и тржишта рада. Зато треба смањити број оних који напуштају школовање, јер се очекује да 2020. године буде око 40\% становништва са високом стручном спремом, док ће потребе за радницима бити мање.

$\mathbf{У}$ двадесет седам земаља ЕУ има око деветнаест милиона студената и милион и по наставника који су ангажовани на 4000 високошколских установа. У 2007. години на еврпским универзитетима докторске студије студирало је скоро 526000 студената, док је тај број у САД био 396,2 хиљаде, а у Јапану 75,5 хиљада. Што је веће издвајање за науку, технологију и високо образованје, то је и већи број докторанада. Зато је важно напоменути да се код нас издваја само 0,9 \% БДП-а за високо образовање и $0,3 \%$ за научна истраживања, за разлику од развијених земаља ЕУ у којима се издваја чак до 4\%, као рецимо у Шведској, док је у неким азијским земљама тај проценат далеко већи.

Зато се универзитети умрежавају. Конференција универзитета Србије део је, између осталог, Европске асоциајције универзитета / ЕАУ/ која има 850 чланова из 47 земаља. Тако је створен јединствени форум за сарадњу и размену. КОНУС је такође и члан Дунавске, Црноморске и Балканске асоцијације универзитета. Могуће је, на пример, организовати заједничке мастер студије на енглеском језику, сворити већу мобилност студената, професора и предавача, кажу професори. Професорка Мини Корназова испред Дунавске ректорске конференције каже да ће наредни кораци зависити од смих универзитета дуж Дунава, те да ће кључну улогу у томе имати универзитети у Србији због своје снажне академске позиције. Академик Јоргаћ Качани каже да до сада Црноморску ректорску конференцију чини 120 универзитета, да ће будући председник ове мреже бити са Универзитета у Београду, што говори о занчају нашег универзитета и важности коју српски универзитети имају за будућу сарадњу између црноморских универзитета и региона. Оно што је такође потребно високошколским установама јесте дефинисање начина рангирања универзитета на локалном, регионалном и европском нивоу. 
Страни предавачи све чешће ће држати предавања не само докторандима, него и студентима мастер и основних студија. Циљ је осавремењавање наставе, боља међууниверзитетска сарадња, али и тежња да се покаже да у савременом свету сваки грађанин Европе треба да, осим матерњег, говори још два светска језика. Потребно је и развијати информатичке алате који помажу опстанку језика у новом добу, поручују научници. А то без добрих филолога није могуће. У ту сврху, постављања образовања и науке на места која им припадају јесу и вести, извештаји, репортаже, интервјуи, емисије Информативног програма РТС-а. Такође, као неакадемски партнер РТС учествује у Темпус пројектима. Јер: “Медији немају слободу да стварају непостојеће друштвене вредности, иако могу утицати на начин на који ће се друштвене вредности исказивати." /Роленд Лоример, МАСОВНЕ КОМУНИКАЦИЈЕ, Clio, 1998; стр. 312/

\section{О медијима}

Реформа високог образованја и код нас и у свету је дугорочан процес. Медији генерално прате и информишу о високом образовању и знатно утичу на реформу у њему. Главни актери високог образовања: студенти, професори, декани, ректори универзитета, владе, министарства просвете и науке истовремено су у главној улози на програмима медија о високом образовању. Самим тим и медији знатно утичу на садржај и поруке јавности о високом образовању.

Без обзира на то као су их корисници медија примили и декодирали, несумњива је узрочно-последична веза - поруке и садржаји су на процес реформе високог образовања, а ферорме на садржај и прогреме медија. Јер путем Инернета /CAJT-a PTC-a, на пример/ постоји могућност тематског претраживања по кључним речима и темама. Ако желите нешто да дорадите, прецизирате, постоји опција гледања рубрика и емисија које су већ емитоване у времену које вам одговара. Можете да оставите и свој коментар, а постоји и опција гледања ТВ путем Инетрнета. Не треба заборавити да рачунари међусовно комуницирају по јединственим правилима, као би се окалшао пренос и размена података. Тако је, на пример, у Интернет новембра 2006. године било укључено 1086250903 рачунара. Како се нањему 
налази огромни број јавних информација, он практично представља својеврсну банку знања. Тако су средстав масовних комуникација данас тесно повезана. Захваљујући напретку технологија, пре свега ширењу Интернета, ова средства се умножавају /видео-игрице, ЦД, мобилни телефони, сателитске антене, кабловски линкови/ и преплићу, па се тако мења њихова улога у друштву и начин њиховог деловања. Гледаоци данас постају све захтевнији - нарочито млада популација која је све мање заинтересована за праћење калсичних медија и пасивну понуду програма.

Континуирано реформом образовања бави се штампа, а од телевизија једино Информативни програм РТС-а. Гледаност Дневника 2 РТС-а је изузетно висока. Од 365 дана у години Дневник је бар 320 дана убедљиво најгледанија емисија на свим телевизијама са око два милиона гледалаца у просеку сваке вечери, и са “шером” тек нешто мањим од 50 одсто, што практично значи да је сваки други телевизор у Србији у пола осам увече “окренут” ка Дневнику. Осим централог Дневника у 19,30 и остале информативне емисије су прилично гледане. Теме из области образовања су у тим емисијама свакодневно присутне и заступљене.”

Свако озбиљно новинарско истраживање, уз одређену научну апаратуру и методе научног истраживања може да се преточи и у научни рад. У раду могу да се користе квантитативне и квалитативне методе истраживања. У анализовању садржаја и порука емитованих прилога - дескриптивна и упоредна метода.

“Језик никад није сам по себи ни добар ни лош, него може само бити добро упопотребљен (ако одговара одређеној ситуацији) или лоше употребљен." /"Лингвистика о човеку", Ранко Бугарски, Просвета, 1983, стр. 191/ Својеврсна употеба језика у медијима, слузи стварању разноврсних фактографских, аналитичких и белетристичких порука намењених широком кругу корисника. У остваривању ових порука новинар се служи стандардним, народним, научним, поетским, административним, политичким језиком, а према захтеву медија и жанра, личног језичког осећања и друштвеног контекста, и зато је новинарски стил својеврсно јединство свих у нас постојећих језичких употреба./ У оквиру општег новинарског стила, сваки новинар изграђује свој стил, којим издваја себе као ствараоца, као писца, 
као друштвено биће, као оцењивача стварности, чиме остварује специфичну комуникацију са читаоцима, слушаоцима или гледаоцима.

Новинари у вестима, развили су својом дугогодишњом праксом један нови језик чија је сврха да, у што је могуће краћем времену, преноси највише информација, прецизно и непристрасно. Нажалост, постоји лоша страна таквог језика, јер се гледаоци после емисије присећају тек 22 одсто вести и тек сваки десети гледалац њихов садржај може да понови. Циници примећују да се ТВ вести не праве за сећање него за заборав. У ставри, опасност је у томе што нам телевизија уместо размишљања нуди још само храну за очи.

Међутим, задатак јавног журнализма је да догађаје покрива из угла грађанина (а не стручњака) јер су гледишта обичног човека важна колико и ставови експерата. Док гледате ТВ програм истовремено су ангажована и чуло слиха и чуло вида тако да концентрација током читаве емисије не пада. У свету учење изван учионице никад не престаје, подсећају аутори „Теорије знања“. Владе постављају комисије; армије се ослањају на интелигенцију, извиђање, осматрање; научници руководе истарживањима; доктори константно откривају нешто ново; професори се старају о професоналном усавршавању; новинари проверавају своје изворе; музичари траже боље путеве /начине/ да компонују; филозофи преиспитују своје концепте..... Једноставно - ради се о доживотном учењу - life-long learning.

За гледаоце Информативног програма РТС-а говиорили су и студенти и професори, ректори и министри, представници Европске уније, амбасадори земаља са којима Србија има унивезитетску сарадњу. Јер кроз призму културе, образовања, медија треба да се покаже каква је и колика је улога медија у образовању гледалишта и приближавања различититих култура, колико смо као културе и друштво спремни да сарађујемо, на којим пољима и колико уважавамо једни друге. Уосталом, лингвисти сматрају да медији имају знатно већи утицај на општу језичку културу, на народне масе него школе и књижевност. А међусобна интеракција језика и телевизије је веома значајна.

"У савременим развијеним друштвима и државама примарни стратешки систем који се издваја и издиже изнад свих осталих, јесте образовни систем. Јер образовање и њему примерено знање омогућавању надокнаду свих других врста која нам недостају, а потребна су 
за нормалан и достојанствен живот. Зато га је потребно одмах материјално опоравити, а потом реформисати према светским и европским стандардима". /'Политика и позив", Чедомир Чупић, Чигоја, 2002/

Тако на пример, Јапанска фондација 1970. године интензивира проучавање Јапана у иностранству. Министарство иностраних послова Јапана 1972. године формира тело како би се промовисала јапанска култура, укључујући и учење јапанског језика у свету. Што није лак посао јер “чак и они који представљају већину попилације /у Јапану/ јапански језик пишу и говоре на другачији начин, у зависности од година, пола и образовања.” А у свету око два милиона студената изучава јапански језик. Језик је имао веома важну улогу у међународној и културној политици Јапана, а питања везана за језик, била су и остала блиско повезана и са одређеним глобалним технолошким напретком као и са искуствима мањинских група у самом Јапану. Као било који други језик, усваја дијалекатске варијације, разлике у употреби засноване на полу и друштевном статусу, жаргонима културних подгрупа и страним утицајима.

Катедра за јапански језик, књижевност и културу Филолошког факултета Универзитета у Београду постоји готово цетири деценије. Током боравка у Београду, а поводом тридесетпетогодињице постојања катедре, проф. Икуо Камејама, ректорот Токијксог универзитета одржао је предавања посвећена Достојевском и савременим јапанским писцима. Разматрана је и могућност објављивања заједничких јапанско-српских књижевних и научних часописа.

Као пример онога што би могло да има и образовну и информативну функцију, наводимо прилог емитван у емисији Радио-телевизије Србије „У свету“ емитован 14. децембра 2011. године.

\section{Најава:}

Катедра за јапански језик, књижевност и културу Филолошког факултета Универзитета у Београду постоји већ тридесет и пет година. Највећа је и најстарија катедра јапанистике у Југоисточној Европи. Поводом јубилеја, студенти и професори Токијског универзитета за стране студије представљали су се током тродневног боравка у Београду студентима, професорима и Београђанима предавањима и уметничким програмом. 
TEKCT :

ИТ тон /плес 5 секунди/

Студент III године Токијског универзитета Актум Рата каже:” Поред филипинског језика као главног предмета, студирам и српски јер је интересантан, и јер се Србија налази на раскршћу великих цивилизација, европских и орјенталних, преузимајући утицај нових култура.”

Са Токијским универзитетом за стране језике уговор је потписан прошле године, док неформална сарадња постоји читаву деценију. Два докторанта из Јапана раде као лектори на Филолошком факултету, а отворена је и катедра за српски језик у Јапану.

Проф. Љиљана Марковић, продекан Филолошког факултета Универзитета у Београду подсећа: "Ми сарађујемо, са свим водећим јапанским универзитетима, са универзитетом Чуо у Токију смо прво потписали уговор о сарадњи, то је било у оно давно време када је било веома необично имати такав уговор, и изузетно сам поносна што је Чуо универзитет био први и што већ од 1985. године, ја сам на њему докторирала 1984. ми сарађујемо."

Међууниверзитетска сарадња Србије и Јапана је добра, кажу ректори, а у плану је израда мултидисциплинарних заједничких наставних програма.

Проф. Икуо Камејама, ректор Токијског универзитета за стране студије тврди: " Са Универзитетом у Београду сарађуемо на нивоу научноистраживачког рада, наставничком и професорском нивоу, а ту је и размена студената. Тренутно, десеторо академаца учи ваш језик и желе да по завршетку студија дођу у Србију. За славистику сам се заинтересовао преко Достојевског. Читао сам Злочин и казну када сам имао тринаест година. То је интересовање које ме већ пола века не напушта. Из тога је произашло све остало што сам урадио."

Проф. Бранко Ковачевић, ректор Универзитета у Београду закључује: “Тако да је Јапан један од најзначајнијих партнера, можда звучи чудно, иако је далеко, од Универзитета у Београду... Јапан је земља иновација и технолошка сила тако да смо се договорили да направимо неке заједничке студије и студијске програме где ћемо практично имати заједничке наставнике који ће имати наставу на енглеском језику и они ће бити на отвореном глобалном тржишту и они ће бити понуђени целој Европи и целом свету." 
У протеклих 35 година постојања катедре, 650 студената је дипомирало јапански језик, књижевност и културу, а далеко више их је полагало јапански као изборни предмет. Нашим студентима редовно стижу стипендије Министарства спољних послова Јапана, Јапанске фондације. Обезбеђен је и велики број стипендија за студенте мастер и докторских студија, као и кратких курсева јапанског језика. У настави се користе уџбеници које Јапанска фондација шаље сваке године.

Студент мастер студија Филолошког факултета Александар Павловић се нада да ће један део студија провести у Јапану: "На жалост нисам још увек имао прилике да одем у Јапан, међутим прошле године сам једини студент који је примљен на Рицумејку универзитет, али пошто се десила трагедија у Фукушими нисам отишао. Планови за будућност? Па дефинитивно ћу посетити Јапан, вероватно на докторским студијама, то ми је искрено нада да одем у Јапан на једно две године и да тамо завршим дисертацију."

Урара Ито каже:" Дипломирала сам на Универзитету за иностране студије. Сада радим као репортер на једној локалној ТВ станици на североистоку Јапана. Веома смо узбуђени што смо могли да дођемо овде. За нас је овде прилично хладно, али смо импресионирани вашим гостопримством."

Плесна група Силанган Токијског универзитета за јубилеј највеће и најстарије катедре јапанистике у Југоисточној Европи, али и у знак захвалности народу Србије за солидарност показану након великог земљотреса и цунамија у источном Јапану, извела је Азијску симфонију. У знак захвалности за дугогодишњу сарадњу деканка Александра Вранеш уручила је повеље ректору Икуо Камејами и амбасадору Јапана у Србији Тошио Цунозакију. /И на крају прилога емитиован је део плеса...тако смо на особен начин имали спој више умености и научних области./

Оно што је примарно у Србији то је опорављање и учвршћивање четири система: правосудног, медијског, образовног и здравственог. Академци и њихови професори знали су и знају да декодирају поруке Информативног програма и да реагују на њих. Зато су и сами често тражили помоћ медија да се реши проблем броја бодова за упис у наредне године студија, висине школарина и донесу измене законских прописа. Повратно дејство Универзитета на програм и ТВ програма на Универзитет у области реформе високог образовања као тренд који 
се наставља је ваљан индикатор да се прате и успешно декодирају прилози и поруке о реформи високог образовања. Надамо се да их и на сличан, а можда и на исти начин декодира остатак публике. Не треба заборавити да медији имају снажан, директан и специфичан утицај на понашање појединца. Они могу да постављају „дневни ред“ - питања о којима се води расправа и по којима се понекад, предузимају конкретни кораци. Доминантне вредности комплексно су енкодиране у медије, али гледалац може да их декодира на различите начине. Осим тога, средства комуникације постављају основне параметре функционисања било ког друштва.

Да су теме којима су се бавили и Информативни и Културно-образовни програм добро одабране, говори и то да на жалост, ни данас поред Закона о студентском организовању није још много тога урађено: нисмо добили национални оквир квалификација /мада ће га прво урадити сектор високог образовања, па тек онда средњег/, нема интегрисног универзитета, јер сваки факултет и даље хоће да остане правно лице /рецидив не социјализма, већ комунизма, јер су факултети постали правна лица 1954. године/, није заживела одредба да држава и универзитет сваке године закључују уговопр о финанситању, није повећана стварна мобилност студената /за шта је опет потребан новац/, антагонизам приватних и државних универзитета и даље постоји. Ваљало је све ово пратити и кроз емисије Образовног и Научног програма, јер треба вратити младе правим вредностима.

\section{О знању}

Да би друштво постало друштво знања, оно мора да буде друштво које стално учи (lifelong learning society). Беконова идеја "Знање је моћ” остварује се управо у овом веку у економији знања. Тако тешко мерљив ресурс као што је знање, управо је и најзначајнији ресурс светске привреде XXI века. Зато је ова област предмет истраживања различитих научних дисциплина.

Управљање знањем подразумева и посебан начин доношења политичких, стратешких и тактичких одлука. То се пре свега односи на образовање, науку, иновације и информационо друштво, јер се они управо баве знањем. У ту сврху, оно мора да буде ефикасно, 
ефективно, флексибилно, транспарентно и кохерентно. А управо му транспарентност обезбеђују и медији. Путем медија знање може и да се преноси, а читаоци, слушаоци, гледаоци, едукују. Тако знање треба да постане основни стратешки ресурс сваке организације. Потребно је створити употребљиво ново знање и избегавати његову злоупотребу. Зато се у оквиру концепта мора водити рачуна и о етици и друштвеној одговорности.

Очигледно да заборављамо на Сократову мисао “Ја знам да ништа не знам", јер људи све чешће подцењују вредност онога што не знају и прецењују вредност онога што знају. "Информације су одувек биле извор моћи, али су данас све више извор забуне. У сваком домену савременог живота, хронични услови су презасићени информацијама које су слабо интегрисане или изгубљене негде у систему. Снажна карактеристика истраживања КН ( мрежа знања ) јесте да се оне налазе на размеђу толико важних теоретских и политичких питања као што су прожимајући трендови који окружују глобализацију и " смањивање " нашег света; све већа сложеност и брисање граница што је представљено у новим организационим формама; тешки, лични изазови за избор каријере појединца и за оданост избору. Ти трендови воде до дилема, како за појединце тако и организације у процесу развоја и дељења знања у мрежама. Дефинисао сам знање, раздвајајући га од уобичајених термина као што су ИНФОРМАЦИЈЕ И МУДРОСТ." ( "Managing Knowledge Networks", J. David Johnson, Cambridge University Press, 2009, str.278)

Један од суштинских проблема знања јесте тај што га је тешко "поседовати" у истом смислу као и неке физичке предмете. Отуда и питање “чије је онда знање, посебно ако признамо да је оно нераздвојиво друштвено. Није суштина у томе шта неко зна, већ у све већој способности за знањем, да се производи ново, активно знање, много брже него што су то радили наши преци".(Ibidem, str.278).

Обично је инфраструктура наших медија производила информациона поља која информишу. Она се усклађују како би обезбедила информацје које изаберу а која потом употребљавају њихови слушаоци. "Велика сметња трагању за информацијама за неке групе јесте недостатак потребних вештина, а неке су од тако суштинске важности попут недостатка писмености. Трагање за 
информацијама се јасно разликује са нивоом образовања појединаца. Према томе, важно је не само обезбедити приступ правом путу до информација већ људи морају да добију и неопходну обуку да би их користили.” (Ibidem, str.282)

Равнотежа сарадње и конкуренције мора се остварити, посебно у деоби информација које су у интересу друштва, упркос гомилању појединачних мотива. Што се више напора усмерава ка специјализацији, што подразумева корист од рада других људи, то ће појединац бити више неспреман да се одрекне онога што зна. Зато је, сматрају стручњаци најбољи мотив за деобу знања осећај за колективитет и реципроцитет. А да је знање најзначајнији ресурс 21. века, то су најразвијеније земље већ схватиле издвајајући и до 20, па и 30 одсто бруто домаћег производа за обтазовање и науку, или попут Аустралије која има 40 одсто факултетски образованог становништва, а њени факултети сматрају се једном од највећих извозних грана / трећа извозна грана у земљи после угља и гвожђа/. Јер век у којем живимо, означен је као век знања, што подразумева да је знање роба односно интекелтуална својина која ће имати своју цену на тржишту и тиме својим власницима обезбедити посебан положај у друштву.

По Болоњском процесу студнети су у центру пажње. Очигледно је да је у нас већина академаца инертна и да не зна све механизме како да своја права и обавезе оставри на прави начин. С друге стране, ресорни министри најављују боље Законе за студенте, бољу сарадњу наших и страних научника до краја ове деценије. Пратећи резултате тих најава, чекамо 2020. годину. Уосталом, не треба заборавити да је институција универзитета, настала пре 927 година, успела да преживи готово читав миленијум и да остане темељ на којем почива савремена цивилизација само захваљујући томе што је умела да се непрестано прилагођава.

Или како то каже ENQA: This is the beginning, not the end of the job, quality assurance is a journey, not a destination.

\section{Литература:}

Бугарски Ранко; 1983; Линївисӣика о човеку; Просвета; Београд 
Бугарски Ранко; 1996; Језик у gрушишву; Чигоја, Београд

Биргс Адам и Пол Колби; 2005; Увоg у č̄ygujy меguја; Клио, Београд Vikipedija

Johnson J. David; 2009; Managing Knowledge Networks; Cambridge University Press

Лоример Роленд; 1998; Масовен комуникащије; Клио; Београд

Мала енциикойеgија Просвейа, 19 ;Просвета, Београд

Мимица Аљоша и Марија Богдановић; 2007; “Социолошки речник”; Завод за уџбенике; Београд

Sue Newell, Maxine Robertson, Harry Scarbrough, Jacky Swan; 2009; Managing Knowledge Work and Innovation; Palgrave Macmillan

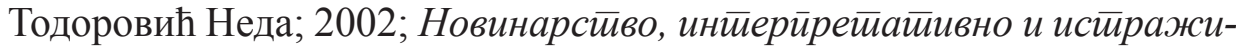
вачко; Чигоја, Београд

Чупић Чедомир; 2002; Полийика и йозив; Чигоја, Београд

\section{Остала литература:}

Подаци центра за истраживање РТС-а

Рубрике емитоване у информативном програму, дневнику РТС-а

Natalija Sinanović

\section{Summary}

\section{EDUCATION AND MEDIA}

The society to become the society of knowledge must be the one that constantly learns. For that purpose, putting education and science on places they deserve is the role of news, reports and TV broadcasts. Therefore, the academic community, education, science, culture and viewers should be connected in the best possible way.

Key words: reform of higher education, university, professors, students, media, Serbian Broadcasting Corporation, knowledge management, viewership, influence 